\title{
NO PRINCÍPIO ERA O TEXTO: DOM CASMURRO NO PAPEL, CAPITU NA TELA
}

\section{MARIANA MILLECCO}

Universidade Federal do Rio de Janeiro

Rio de Janeiro, Rio de Janeiro, Brasil

Resumo: Construído a partir de conceitos, signos, símbolos, relações materiais e imateriais, o figurino apresenta um arsenal de informações a respeito da encenação. $\mathrm{O} /$ A figurinista trabalha um objeto que vai vestir o corpo e com ele ajudar a compor a visualidade da cena proposta. Este artigo é uma análise da construção do figurino e visual de Capitu, a famosa personagem de Dom Casmurro de Machado de Assis, na minissérie veiculada pela Rede Globo de Televisão e dirigida por Luiz Fernando Carvalho (Capitu, 2008). Por meio desse trabalho vamos refletir sobre o caminho percorrido pela figurinista Beth Filipecki até a construção da imagem que vimos de Capitu. Para tanto foi realizada uma entrevista em duas etapas (2013), o método empregado foi o Método de Explicitação do Discurso Subjacente - MEDS, formato de entrevista para pesquisa qualitativa narrativa específica, que, além de ocasionar uma construção de pensamento contínuo na resposta, proporciona a melhor percepção do discurso explícito e implícito nela contido. Nestas oportunidades foram coletadas, além das informações aqui apresentadas, imagens do acervo pessoal de Filipecki, e foram fotografadas peças do acervo pessoal de Filipecki usadas na minissérie.

Palavras-chave: Figurino; construção visual; Capitu; Dom Casmurro; Machado de Assis.

\section{IN THE BEGINNING WAS THE TEXT:}

\section{DOM CASMURRO ON PAPER, CAPITU ON THE SCREEN}

Abstract: Built from concepts, signs, symbols, and material and immaterial relationships, costumes present an arsenal of information about staging. The costume designer works an object that will dress the body and help it to compose the visual aspect of the scene at hand. This article is a study of the visual construction and costumes of Capitu, the famous character from Dom Casmurro by Machado de Assis, 
in the miniseries of the same name broadcast by Globo TV and directed by Luiz Fernando Carvalho (Capitu, 2008). Through this work we will reflect upon costume designer Beth Filipecki's process in constructing and settling on the image of Capitu we see. This was achieved by conducting a two-part interview (2013) that used the methodology known as Underlying Discourse Unveiling Method - UDUM, an interview format adapted for specific qualitative narrative research, which, besides giving rise to a construction of continuous thoughts in the answers, provides a better notion of both its implicit and explicit discourses. Besides the information presented here, these occasions afforded the collecting of images from Filipecki's personal archive and pieces from Filipecki's personal archives were photographed and used in the miniseries.

Keywords: Costume design; Visual construction; Capitu; Dom Casmurro; Machado de Assis

Eu retratava a palavra com meu corpo, para que ela pudesse ver e sentir.

Pina, Wim Wenders, 2011

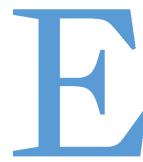

m 2008 a Rede Globo de Televisão exibiu a minissérie Capitu, adaptação ou, como o diretor Luiz Fernando Carvalho prefere denominar, um diálogo com a obra Dom Casmurro, de Machado de Assis. Parte integrante de um projeto pessoal do diretor, ${ }^{1}$ o Projeto Quadrante, a construção visual da personagem título desse produto pelas mãos da figurinista Beth Filipecki é o objeto de observação deste artigo.

\footnotetext{
${ }^{1}$ Diretor de cinema e televisão, no cinema escreveu e dirigiu o longa-metragem Lavoura arcaica (2001), transposição da obra de mesmo título do escritor Raduan Nassar. Na televisão dirigiu os especiais: $O s$ homens querem paz (1991), Uma mulher vestida de Sol (1994) e A farsa da boa preguiça (1995); as novelas: Renascer (1993), O rei do gado (1996) e Esperança (2002); as minisséries: Os Maias (2001), Hoje é dia de Maria (em duas partes, a primeira em janeiro e a segunda em outubro de 2005), A pedra do reino (2007) e Afinal o que querem as mulheres (2010); em 2014 dirigiu para o Fantástico quadro baseado em textos que Clarice Lispector escreveu, sob o pseudônimo de Laura Palmer, para suplementos femininos dos jornais Correio da Manhã e O Comício.
} 
$\mathrm{Na}$ entrevista de 2013, Filipecki declarou que a pesquisa para a personagem (assim como para todo o figurino) partiu também das palavras, do texto. ${ }^{2}$ Após ler a obra, a figurinista selecionou algumas imagens que, no entanto, não foram aproveitadas para a construção definitiva da personagem e representavam uma Capitu infantil, romântica, cândida; passarinho, anjo, flor do jardim de Pádua. Eu as apresentarei por julgar o registro importante para o entendimento da pesquisa do figurinista como um processo vivo (figura 1):

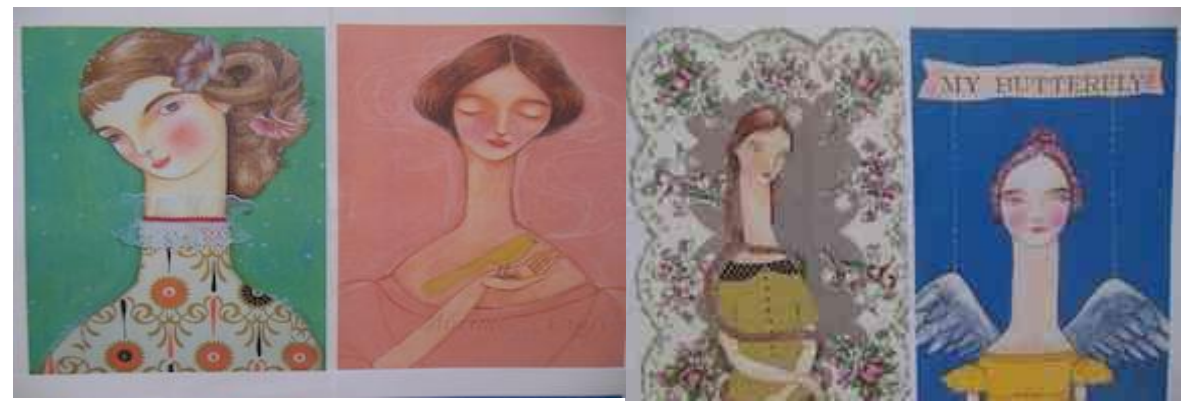

Figura 1

Com o evento da apresentação da atriz Letícia Persiles, escolhida para o papel de Capitu menina, Filipecki percebeu que precisava de outras imagens para trabalhar com sua personalidade e atitude, com a Capitu que ela já trazia dentro de si e com a Capitu que o diretor nela enxergava. A imagem seguinte (figura 2) mostra uma foto de Letícia Persiles tirada antes do início da gravação da minissérie, na qual a atriz já revela a postura que adotaria como Capitu nas gravações:

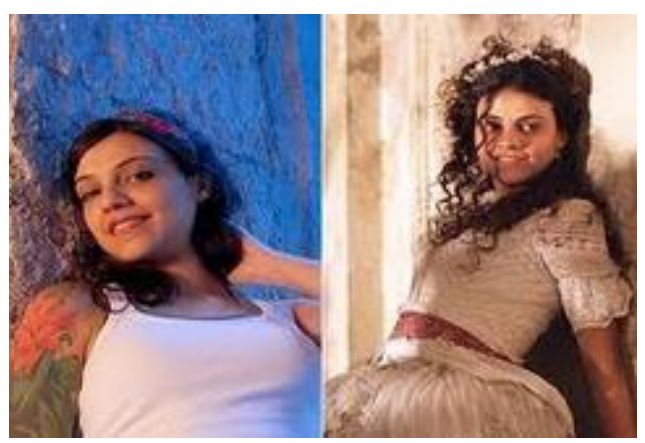

Figura 2

\footnotetext{
${ }^{2}$ Maiores referências, assim como a entrevista com a figurinista, encontram-se no trabalho Capitu: pela análise de um figurino e por um resgate e reconstrução da metodologia de trabalho de Beth Filipecki, apresentado na conclusão de curso de mestrado do Programa de Pós-Graduação em Artes Visuais, EBA/UFRJ, em abril de 2015.
} 
No que diz respeito à definição do período histórico, a simbologia do mar extraída dos olhos de ressaca de Capitu permitiu que a minissérie transcendesse a sua fixação em uma época específica, a qual é no romance a segunda metade do século XIX. A temporalidade da minissérie move-se num vai e vem, um ir e vir, fundindo a paisagem e a vida urbana dos telespectadores com as do Rio do tempo histórico da obra literária. Uma das passagens em que essa simbologia se torna explícita encontra-se no capítulo XXXII do romance:

Retórica dos namorados, dá-me uma comparação exata e poética para dizer o que foram aqueles olhos de Capitu. Não me acode imagem capaz de dizer, sem quebra da dignidade do estilo, o que eles foram e me fizeram. Olhos de ressaca? Vá, de ressaca. É o que me dá ideia daquela feição nova. Traziam não sei que fluido misterioso e energético, uma força que arrastava para dentro, como a vaga que se retira da praia, nos dias de ressaca. Para não ser arrastado, agarrei-me às outras partes vizinhas, às orelhas, aos braços, aos cabelos espalhados pelos ombros; mas tão depressa buscava as pupilas, a onda que saía delas vinha crescendo, cava e escura, ameaçando envolver-me, puxar-me e tragarme. ${ }^{3}$

O mar carrega, traz, guarda e preserva, traga e transforma... E essa foi a metáfora que permeou toda a construção e definição conceitual do figurino de Capitu, como diz Beth Filipecki:

[...] você vai ver que tem coisas que de fato são de outras épocas que eu queria né?! (é acumulativo) como tem o mar, e o mar guarda os tempos, né?! Eu queria que ela tivesse toda essa conotação... E foi muito bom, porque... ela é linda, fácil! E ela já estava acumulando, porque ela estava grávida! Eu estou falando da Maria Fernanda... Ela teve bebê um mês depois [do final das gravações]...4

Duas referências que nortearam o processo de construção do figurino, desde o trabalho de pesquisa à confecção das peças, foram o livro Galliano, de Colin McDowell, e o trabalho do fotógrafo Miguel Rio Branco. O livro Galliano foi assunto de uma reunião entre Luiz Fernando Carvalho, os atores e a equipe de produção. Nele Colin McDowell retrata uma parte da trajetória

${ }^{3}$ ASSIS, Dom Casmurro, p. 66.

${ }^{4}$ FILIPECKI, 2013, apud RIBEIRO, 2015. 
e da obra do estilista John Galliano, à época, da Maison Dior, seus processos de trabalho e sua personalidade. ${ }^{5}$ Carvalho, que introduziu o livro na discussão, considera-o uma grande referência imagética para a minissérie, referência esta que se mostraria posteriormente ainda mais significativa para o figurino, como veremos a seguir.

$\mathrm{Na}$ entrevista, Filipecki também cita como uma das primeiras respostas à sua busca pela linguagem do figurino uma reportagem publicada no jornal $O$ Globo, ${ }^{6}$ sobre o trabalho do fotógrafo Miguel Rio Branco, ${ }^{7}$ na qual se observa uma montagem de fotos que mostra a espuma do mar e tecidos de igual movimento. Essas duas referências nortearam grande parte do processo de pesquisa e inspiração para o figurino da minissérie, pois não só deram o tom e a forma para a construção de seus personagens, como também desencadearam uma filosofia interpretativa para Capitu.

Observam-se então cinco questões fundamentais para se entender o figurino da personagem-título: o arquétipo do mar, a entrada da atriz Letícia Persiles no projeto, o livro de Colin McDowell apresentado pelo diretor e o encontro de Filipecki com a obra de Miguel Rio Branco. Somando-se a esses fatores, a escolha do antigo Automóvel Clube no centro da cidade do Rio de Janeiro como cenário quase único a ser utilizado traz uma aura decadente e degradada, ambientes amplos e de pé-direito alto. Alinhavadas a essas questões, seguiram-se então todas as outras ações inerentes ao processo de trabalho da figurinista. Durante a ordem sequencial dos fatos e da análise realizada da aparência que o figurino ia adquirindo, registrou-se a influência de cada uma dessas formas e inspirações. É importante considerar que, enquanto a figurinista realizava seu trabalho, paralelamente aconteciam os trabalhos de toda a equipe como: direção de arte, cenografia, iluminação etc. E cada decisão tomada influenciava mutuamente as áreas de produção.

Ao olhar para a personagem Capitu menina, e no movimento de começar a definir a sua imagem, Filipecki parte da silhueta para finalmente chegar à forma de construção do figurino. Este é um costume da figurinista; faz parte do seu processo definir como primeiro elemento a silhueta da personagem e, posteriormente, como essa silhueta será "preenchida". Para a

\footnotetext{
${ }^{5}$ McDOWELL, Galliano, 1997.

6 "Miguel Rio Branco mostra, no Rio e na Holanda, que a montagem é a essência da sua obra". $O$ Globo, Rio de Janeiro, 23 set. 2003, Segundo Caderno, p. 10.

${ }^{7}$ Miguel Rio Branco nasceu em 1946, filho de diplomata brasileiro, neto e tataraneto de um barão e um visconde; é pintor, fotógrafo, diretor de cinema, além de criador de instalações multimídia. Iniciou sua carreira em 1964 com uma exposição em Berna, na Suíça, mas atualmente trabalha e vive no Rio de Janeiro.
} 
Capitu menina foi apresentada a silhueta infantil da época. Capitu tem catorze anos em 1857, quando começa a narrativa de Bento Santiago. ${ }^{8}$ Devido a sua personalidade e às características do espaço cenográfico da filmagem (o prédio do Automóvel Clube e suas dimensões teatrais e operísticas), a mancha ou silhueta de Capitu foi aumentada na base (figura 3):

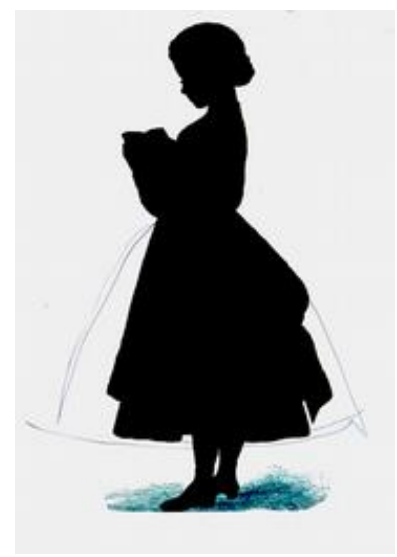

Figura 3

Capitu é plena, segura de si; tem a base larga de quem sabe seu lugar e domina o espaço que ocupa. Sua forma foi preenchida em camadas que traduzem sua personalidade enigmática, de certo modo os vários níveis interpretativos da obra, e a sua natureza misteriosa, ou natureza "enviesada", nas palavras de Filipecki. Trabalhou-se a feitura do figurino na minissérie (como uma orientação geral para as personagens), a partir de bases (agora no sentido de elementos individuais para a formação dessas camadas de vestimenta, a base primeira de sustentação da roupa), e nelas foram sendo desenhadas personagens e demandas específicas para cada cena. Segundo Filipecki:

Foram confeccionadas aproximadamente 60 bases femininas que durante todo o processo sofreram customizações e adereçamentos, que se transformavam em um número infinito de figurinos para diversas ocasiões. Ao utilizar, de modo recorrente, partes dos figurinos para construir outros figurinos, sem ficar presa a esquemas rígidos para cada personagem, pretendeu-se atender a uma leitura arquetípica do romance de Machado de Assis. Assim, adereços da mãe vão estar

${ }^{8}$ As idades dos personagens em cada fase da história foram definidas e/ou presumidas pela equipe de direção e, à medida do necessário, enviadas para consulta por toda a produção. 
presentes, ordenados em outra direção, nos trajes simbólicos e volumosos de Capitu. O que mudava era apenas um corte mais enviesado, composto com o famoso olhar da personagem. Os materiais iam e vinham nessas narrativas poéticas e musicais, na encenação imaginativa e enigmática de Dom Casmurro. É no registro da fragmentação que o figurino compõe sua unidade visual, pelo olhar do narrador. [...] Durante todo o processo as bases sofreram customizações e adereçamentos que se transformavam em um número infinito de figurinos para diversas ocasiões. ${ }^{9}$

Para o trabalho de confecção das bases, não foram produzidas pranchas de referência. Segundo Canevacci, "usualmente organizam-se as referências para criação de um projeto, personagem etc. [...] numa prancha de colagens, que não é apenas técnica, mas uma verdadeira filosofia estética". ${ }^{10}$ Ao invés de pranchas, Beth Filipecki optou por pastas e cadernos dos personagens. Mesmo não tendo configurado o que se conhece por essas pranchas, o princípio da reunião das referências é o mesmo, mudando apenas a formatação. Sua função é guiar o processo criativo, condensar ideias e sentidos para a sequência do trabalho e até mesmo despertar novos focos de pesquisa. A própria prancha ou, no caso aqui descrito, o caderno de referência pode ser então fonte inquietante que desperta mais e novos "gatilhos" criativos com a função de abstrair conceitos, sentimentos e afastar a criação da obviedade. Aumenta o campo de possibilidades para transformar a pesquisa na materialidade do figurino desejado. No conjunto da figura 4, vemos algumas referências da pasta de Capitu menina, e na figura 5 uma imagem retirada do livro Galliano e imagem de cena da minissérie em que verificamos referência e figurino realizado:

${ }^{9}$ FILIPECKI, Íntegra da entrevista a Luz e Cena, acervo da figurinista.

${ }^{10}$ CANEVACCI, Fetichismos visuais: corpos erópticos e metrópole comunicacional, p. 66. 


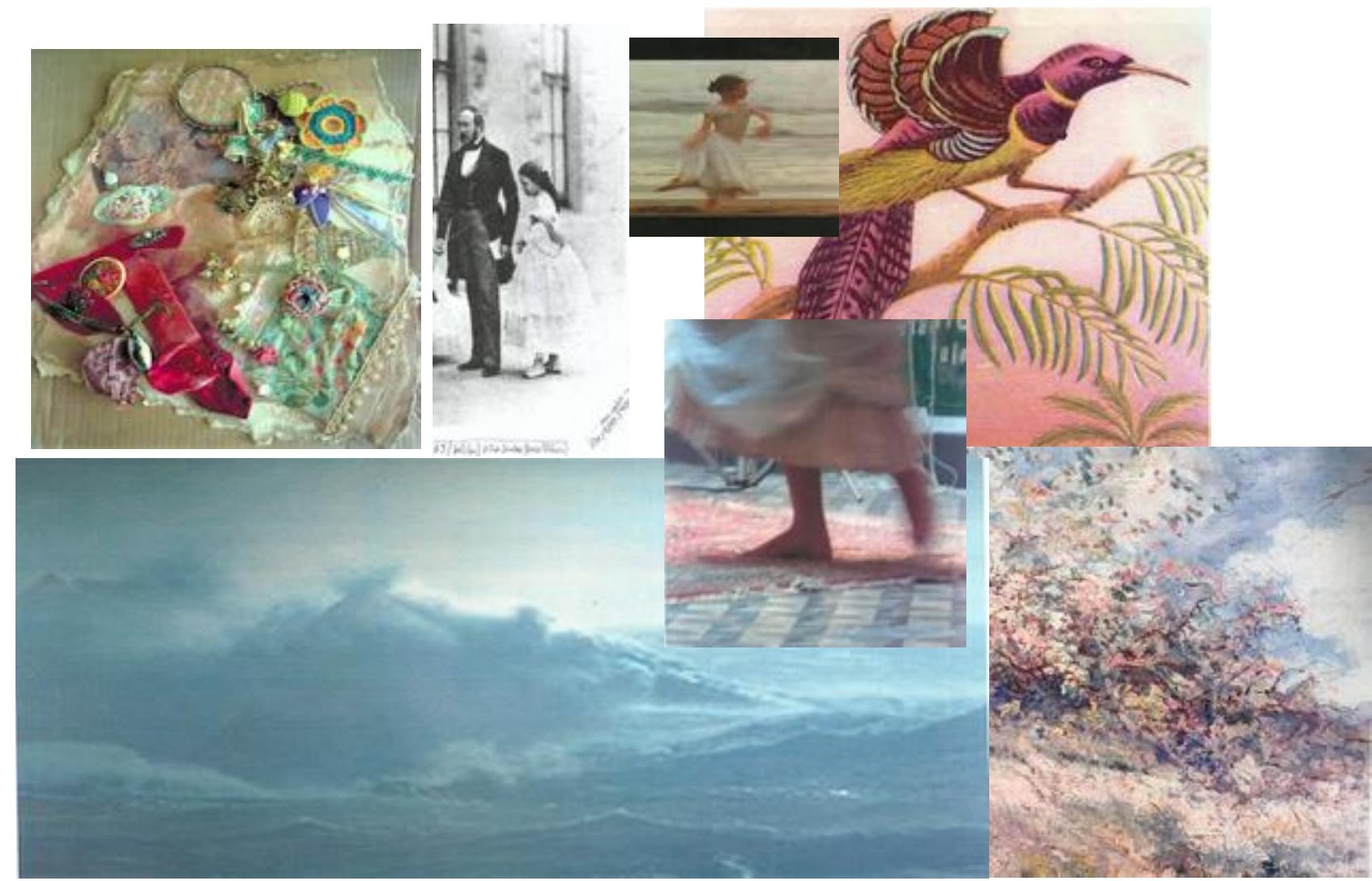

Figura 4
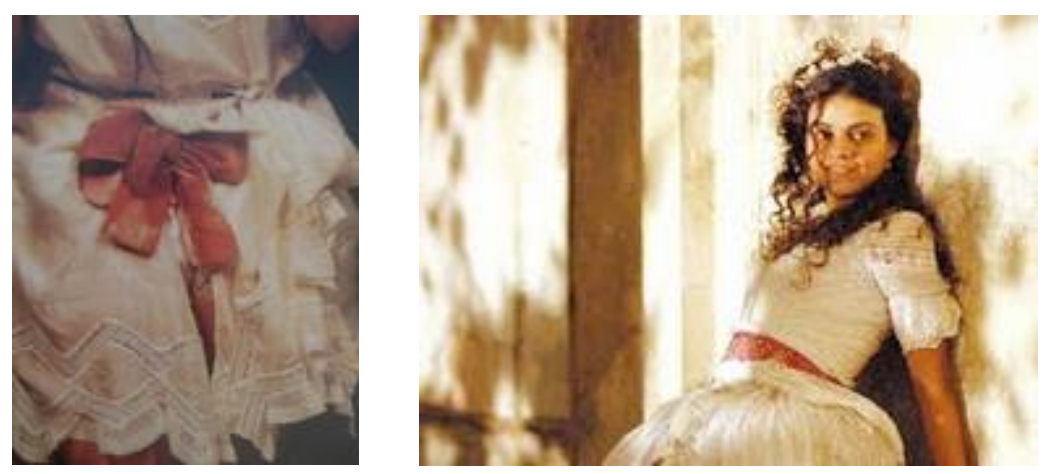

Figura 5

A cor da base das camadas de roupa de Capitu, de menina a adulta, é branca, traz a espuma fresca das ondas que quebram na areia. Consideram-se aqui por base as camadas mais internas de sua roupa, algo como a anágua ou as saias inferiores, em contato mais direto com o corpo da atriz.

Concomitantemente à colagem manual, desenvolvia-se um trabalho de 
manipulação das imagens pelo computador, no qual a imagem de Persiles era trabalhada e inserida na figura desejada para a personagem (figura 6). Então a roupa começou a ser experimentada e montada no corpo da atriz (figura 7):

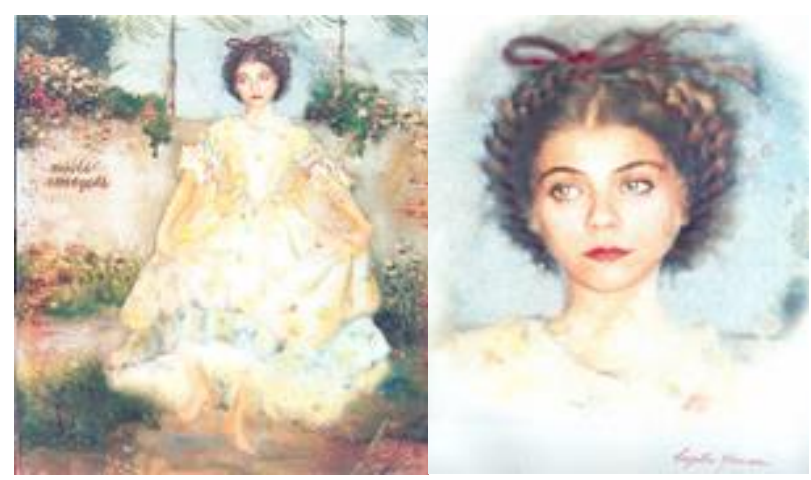

Figura 6

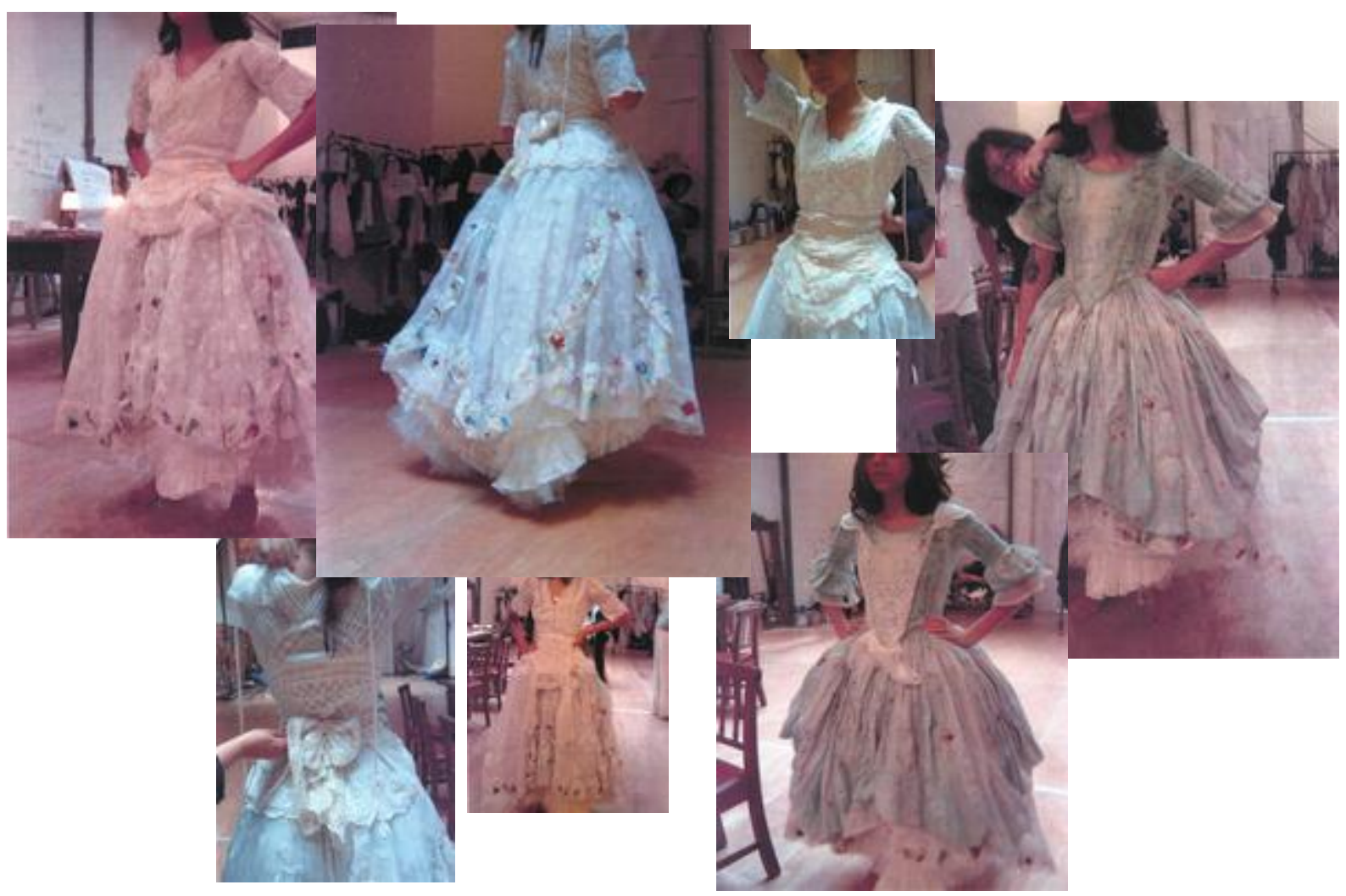

Figura 7 
Capitu já nasce sedutora, e, aos poucos, sua sedução de menina vai aflorando também na encarnação de Persiles. A personagem passa a vida dominando e seduzindo, primeiro sua família, seu jardim (onde reina caprichosamente), depois a vida de Bentinho e sua família. No conjunto da figura 8, vê-se uma sequência de imagens do filme $O$ piano (1993) e cena de Capitu menina. $\mathrm{O}$ mar, como elemento extrínseco à personagem, empresta movimento e sensação de liberdade tanto para a personagem do filme quanto para a personagem-título da minissérie:

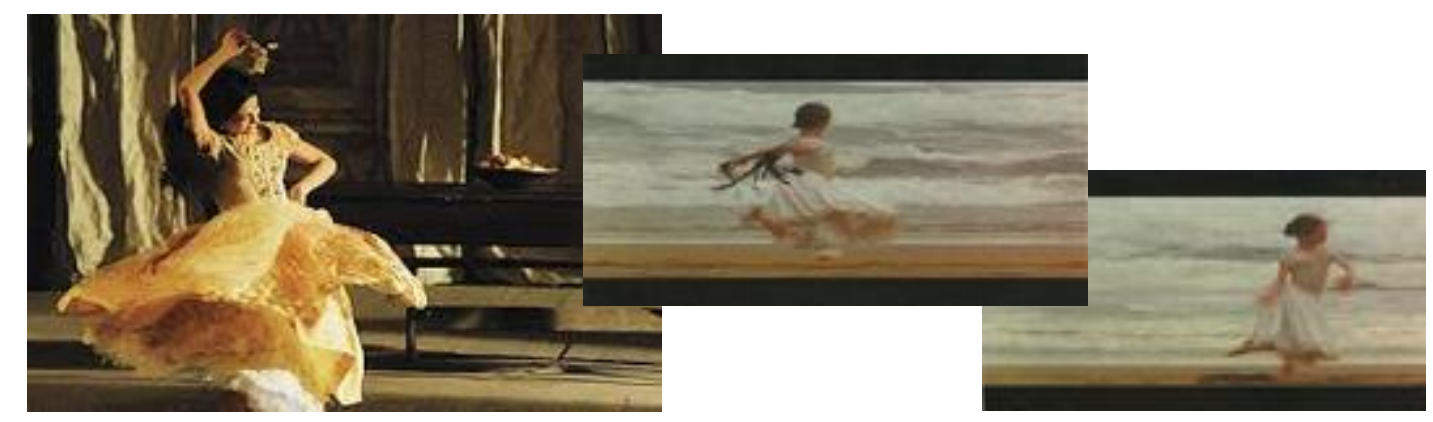

Figura 8

Como suas roupas, Capitu só faz aumentar os territórios de seu domínio, conquistando a tudo e a todos. Até mesmo José Dias, com sua predisposição e desconfiança dos olhos de ressaca da menina, termina por se render aos seus encantos. Apesar de ter muitas camadas, o vestido de Capitu possui certa leveza; há displicência em sua sedução, uma inconsequência aparente. Mais curto do que o das outras moças, revela seus tornozelos e pés. Com os pés descalços, Capitolina ciganeia e envolve Bentinho. Suas camadas são enfeitadas com os caquinhos que ela reúne, são detalhes de florzinhas, fitas e rendas, pequenas intromissões e achados, coisas que Capitu junta e guarda ao longo do tempo, seus acúmulos, suas memórias em registro físico, literal e metafórico:

Já disse que era poupada, ou fica dito agora, e não só de dinheiro mas também de cousas usadas, dessas que se guardam por tradição, por lembrança ou por saudade. Uns sapatos, por exemplo, uns sapatinhos rasos de fitas pretas que se cruzavam no peito do pé e princípio da perna, os últimos que usou antes de calçar botinas, trouxe-os para casa, e tirava-os de longe em longe da gaveta da cômoda, com outras 
velharias, dizendo-me que eram pedaços de criança."

$\mathrm{Na}$ roupa, na alma e na pele. Um fato interessante relativo à caracterização e diretamente ligado à concepção do figurino foi a decisão do diretor de manter à vista a tatuagem da atriz, não a maquiando; para ele a tatuagem, bromélia e pássaro que Letícia carrega no braço, seria uma "continuação do jardim de Capitu"12 e ganhou importância a ponto de ter sua presença garantida na reprodução feita no braço da atriz Maria Fernanda Cândido, que viveu a fase adulta da personagem. A tatuagem era a continuação do jardim de sua infância, liberdade selvagem que carregaria em sua personalidade, natureza que brota dela mesma. Capitu é acima de tudo consistente. Mesmo em seus mistérios. E não se sabe mais de onde saem as coisas, como se o trânsito de emoções, conceitos e sentidos ocorresse de dentro para fora, de fora para dentro, por todos os lados. Capitu é movimento contínuo e sinuoso (figura 9).

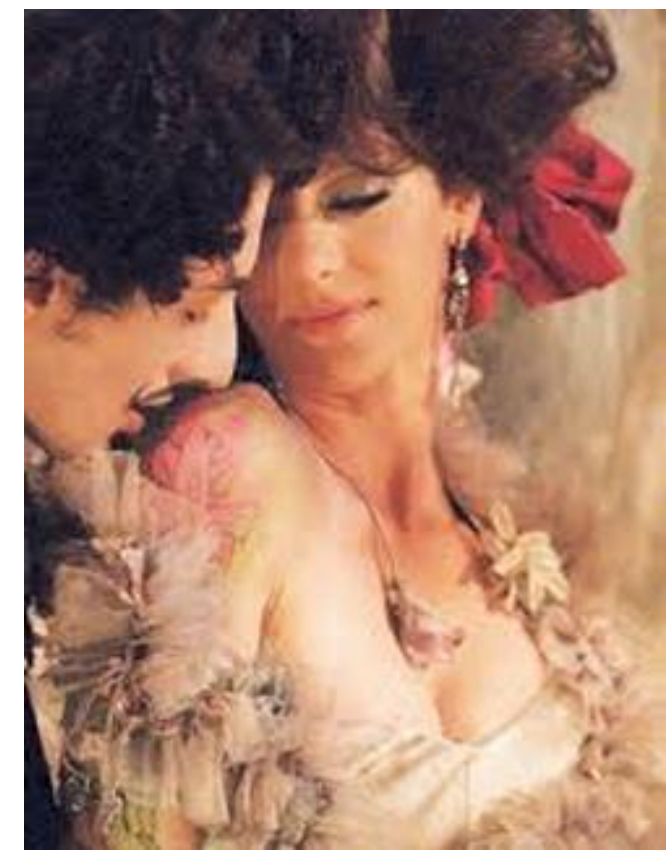

Figura 9

Os cabelos encaracolados de Letícia propiciaram uma visão revoltosa de sua cabeça, como se os pensamentos em profusão da personagem transbordassem em cachos, ondas, tramas trançadas: "Como vês, Capitu, aos

\footnotetext{
${ }^{11}$ ASSIS, cit., p. 176.

12 MENEZES, “Arte na TV”, Luz e Cena, p. 43.
} 
catorze anos, tinha já ideias atrevidas, muito menos que outras que lhe vieram depois; mas eram só atrevidas em si, na prática faziam-se hábeis, sinuosas, surdas, e alcançavam o fim proposto, não de salto, mas aos saltinhos". ${ }^{13}$

$\mathrm{Na}$ meninice, os cabelos de Capitu saltam de sua cabeça e caem vertiginosamente emoldurando seu rosto, banham seus ombros. Com o tempo, a organização de seus pensamentos e atitudes vai domando seus cachos. Durante o período em que Bentinho está no seminário e Capitu se aproxima de d. Glória, essa domação transparece. Nessa fase da juventude já se percebem algumas mudanças. Capitu atenta mais para seu comportamento, conhece cada vez mais seus papéis, assim como reconhece melhor os momentos de utilizá-los. A personagem ganha também, como acessório, o pente, adereço de cabeça que assemelha sua imagem daquela de uma princesa desejosa de herdar o trono da rainha na qual se espelha. Esse acessório se faz mais presente nessa altura da narrativa, quando Bentinho se encontra no seminário, na qual Capitu segue ao lado de sua mãe. Depois, quando já realizado seu desejo de casar-se com Bentinho, seus cabelos ganham um meio-termo entre a contenção e a profusão, a ordem e a desordem. De um lado, suas formas e tons exteriorizam a consciência da personagem; do outro, dão início ao afastamento da perspectiva do olhar de Dom Casmurro em relação a Capitu. Afinal, Bento nunca sequer chegou a ser homem como Capitu foi mulher, ${ }^{14} \mathrm{e}$, à medida que sua personalidade aflora e se consolida, a distância entre o par vai aumentando.

Então os cabelos de Capitu, seus penteados, vão aos poucos domando a selvageria infantil, e seus pensamentos ficam cada vez mais organizados à proporção que ela amadurece. Se antes os cachos dobravam-se soltos, mais madura Capitu os dobra presos e com certa organização. Sua caracterização, entretanto, faz parecer sempre que muitas coisas povoam sua mente, ideias que ocupam também seu corpo inteiro. Os caquinhos, que outrora juntava e que salpicava em seus vestidos, vão progressivamente desabrochar em flores de grandes volumes, agrupadas, subindo e descendo pela roupa, percorrendo sua figura como explosões de energia e complexidade, de luz e sombra. Então, aos poucos, a menina dá lugar à moça, e a moça à mulher.

Segundo Filipecki, durante a pesquisa, o principal elemento formal revelou-se ser a dobra; a dobra no sentido das reentrâncias orgânicas, geografias do comportamento humano, das faces do jogo particular e da vida.

\footnotetext{
${ }^{13}$ ASSIS, Dom Casmurro, p. 43.

${ }^{14}$ Idem, p. 62.
} 
Dentro da cabeça e da narrativa de Dom Casmurro, dentro da cenografia apresentada, são iluminados traços de memória. Tanto esses traços são dobras do pensamento do narrador quanto dobras do autor e sua visão do ser humano, e dobras do comportamento de Capitu:

Quis defendê-la, mas Capitu não me deixou, continuou a chamar-lhe beata e carola, em voz tão alta que tive medo fosse ouvida dos pais. Nunca a vi tão irritada como então; parecia disposta a dizer tudo a todos. Cerrava os dentes, abanava a cabeça... Eu, assustado, não sabia que fizesse; repetia os juramentos, prometia ir naquela mesma noite declarar em casa que, por nada neste mundo, entraria no seminário. $[\ldots]$

Calou-se outra vez. Quando tornou a falar, tinha mudado; não era ainda a Capitu do costume, mas quase. Estava séria, sem aflição, falava baixo (ASSIS, 2011, p. 41).

A forma da dobra traduz e materializa o conceito do comportamento humano presente no texto machadiano - o conceito da máscara social, do jogo, das naturezas do ser humano, do interesse e do desejo $\mathrm{o}^{15}$ - e o conteúdo da própria história contada - a existência ou não da famosa traição, a veracidade ou não dos fatos, e todas as entrelinhas do texto de ficção. A grande "dobra" que Casmurro efetua na vida foi transformar o que seria a vivência de um grande amor numa tragédia familiar, um fim obscuro. É a dobra do comportamento humano que Machado de Assis deixa entrever ou opta por esconder, o enviesamento do olhar desde o de cigana oblíqua e dissimulada da personagem principall6 até o do próprio Dom Casmurro e o de Machado para com a sociedade, o qual extrapola a realidade em surrealidade.

Todas essas dobras deságuam formalmente no figurino. O sentido da dobra e as formas relacionadas foram usados para a construção do figurino por Filipecki, dobras do tecido em si, elementos dobrados uns sobre os outros, detalhes; todos também relacionados ao desdobrar das ondas na praia, que funcionam como materializações conceituais da personagem Capitu. Quando se referem à menina, essas dobras estão mais ligadas à espuma do mar, às camadas de espuma. Franzidas na meninice, ao crescer a personagem aprofunda essas dobras e as transforma em grandes áreas repuxadas, em plissados e movimentos que geram muitas sombras. Percebe-

${ }^{15}$ BOSI, Machado de Assis: o enigma do olhar.

${ }^{16}$ ASSIS, Dom Casmurro, p. 52. 
se que a conceituação segue um padrão: do interior das dobras de Dom Casmurro (o que seria um cérebro senão uma grande massa dobrada e redobrada? Seriam dobras então os caminhos memoriais percorridos pelo personagem em sua narrativa?) às dobras do que ele mostra, imagens das personagens que ele narra em lembranças. E, por fim, desdobramentos dele mesmo. A partir de uma imagem da dobra escolhida pela figurinista e de imagens da espuma do mar, foram feitas mais colagens e desenvolvidos croquis com o auxílio de papel vegetal para orientar a construção da roupa, adereçamento, escolha da cor e tingimento dos tecidos (figura 10). Como diz Deleuze, "finalmente, a própria água dobra, e o apertado e ajustado serão ainda uma dobra de água que revela o corpo melhor do que o faz a nudez: as célebres 'dobras molhadas'". ${ }^{17}$ Agora se trata definitivamente de Capitu adulta:
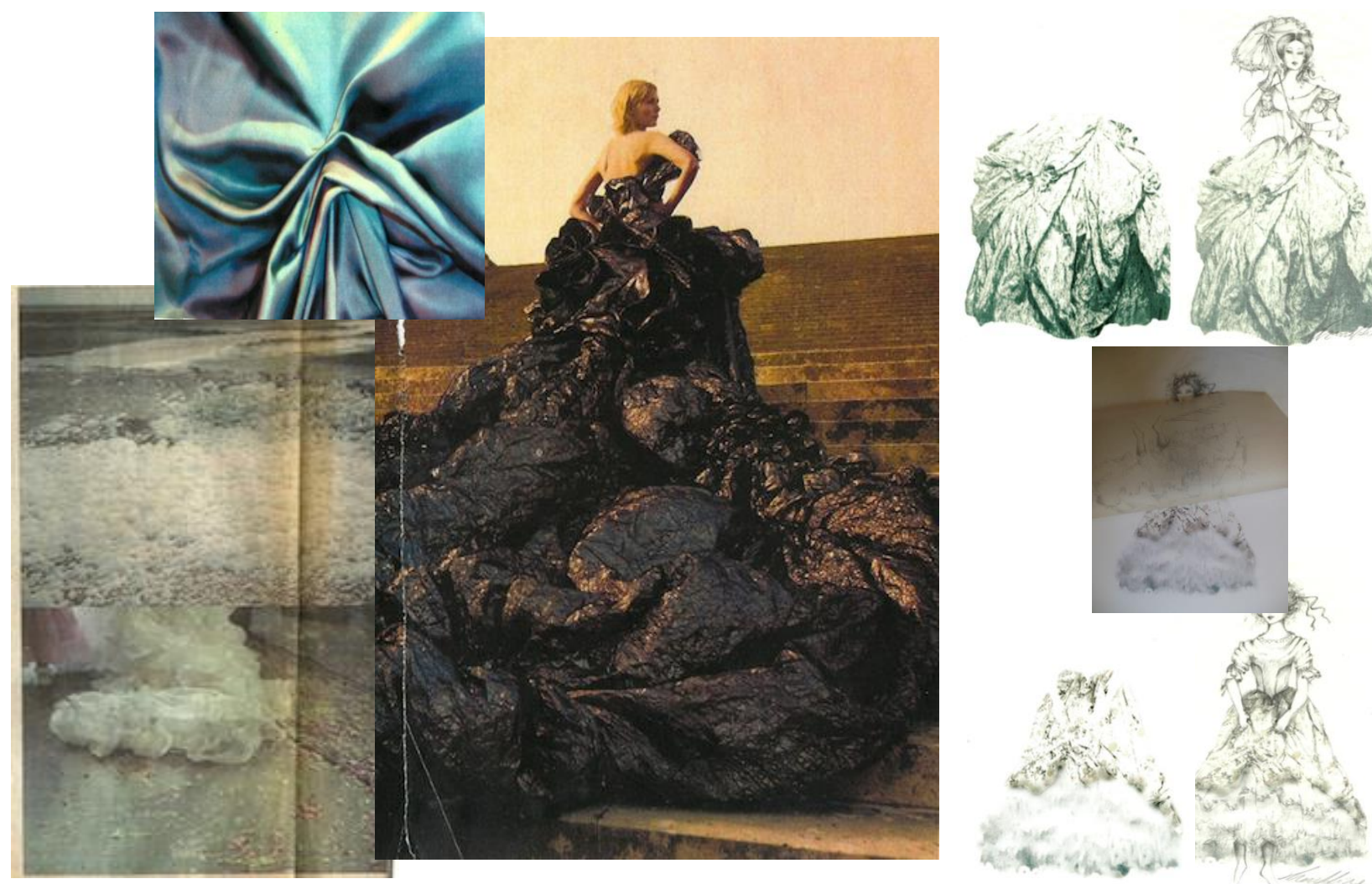

Figura 10

${ }^{17}$ DELEUZE, A dobra: Leibniz e o barroco, p. 209. 
O mais simples é dizer que desdobrar é aumentar, crescer, e que dobrar é diminuir, reduzir, entrar num afundamento de um mundo. [...] Quando Leibniz invoca as vestes superpostas de Arlequim, a veste de baixo não é a mesma que a de cima. Eis por que há metamorfose, ou "metaesquematismo", mais do que mudanças de dimensão: todo animal é duplo, mas de modo heterogêneo, de modo heteromórfico, como a borboleta dobrada na lagarta e que se desdobra. ${ }^{18}$

Em determinado momento, ao refletir sobre Capitu e sua personalidade ao longo da vida, Dom Casmurro apresenta a seguinte conclusão para o seu leitor: "Mas eu creio que não, e tu concordarás comigo; se te lembras bem da Capitu menina, hás de reconhecer que uma estava dentro da outra, como a fruta dentro da casca". ${ }^{19}$ Capitu adulta estava dentro da Capitu menina e ambas, tanto quanto as outras personagens da história, estão dentro da cabeça de Dom Casmurro, nas suas memórias. São produtos de sua organicidade, antes de tudo, visões dentro dele mesmo. A espuma e a dobra são as formas que irão conduzir a construção da roupa, multiplicadas pelos tantos sentidos possíveis ao se analisar o trabalho de construção da minissérie. Nesta fase Capitu já é vivida por Maria Fernanda Cândido. Na figura 11, a seguir, encontra-se um conjunto de imagens da pasta de referências de Capitu adulta, assim como o mesmo trabalho de inserção gráfica da imagem da atriz, composto segundo o mesmo processo utilizado para a imagem de Persiles:

${ }^{18}$ Idem, p. 23.

${ }^{19}$ ASSIS, Dom Casmurro, p. 230. 


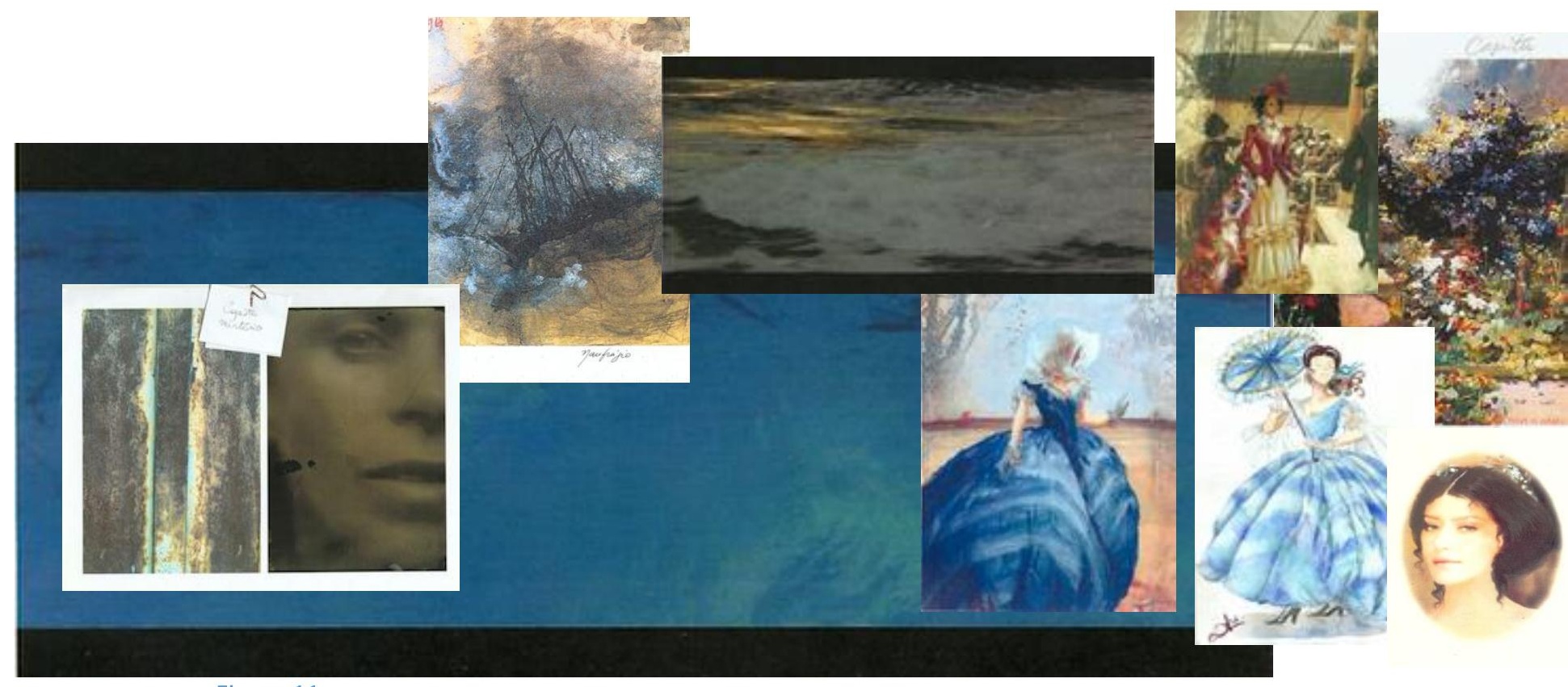

Figura 11

Segundo Filipecki:

Capitu cresce, e seus vestidos passam a ser de renda e organza de seda pura, tecidos do antigo baú de d. Glória, mãe de Bentinho, que ela coloriza e restaura com delicadeza, em camadas de pontos incansavelmente repetidos durante a espera interminável pelo retorno de seu amor. O volume de seus vestidos se derrama e se expande em ondas e luzes. A água mancha as cores das saias e os ventos movimentam as sobressaias em ritmos enviesados e assimétricos. ${ }^{20}$

Ao movimentar-se, a roupa nunca será vista de uma só forma, mas sim em partes, aos pedaços, transformando na memória do espectador a provocação de Machado, as partes da natureza humana, as diferentes faces e máscaras sociais. ${ }^{21}$

Os volumes dos vestidos aumentam ainda mais, o comprimento da saia desce, e chegamos ao momento em que o livro sobre Galliano mais influencia o figurino. Observa-se, nas composições organizadas a seguir, o contraponto de imagens referenciais com cenas da minissérie, em que se veem os babados, plissados e toda sorte de texturas usadas em um e inspiradas no outro (figuras 12, 13, 14 e 15):

${ }^{20}$ FILIPECKI, sem referência de fonte; acervo da figurinista.

${ }^{21}$ BOSI, cit. 


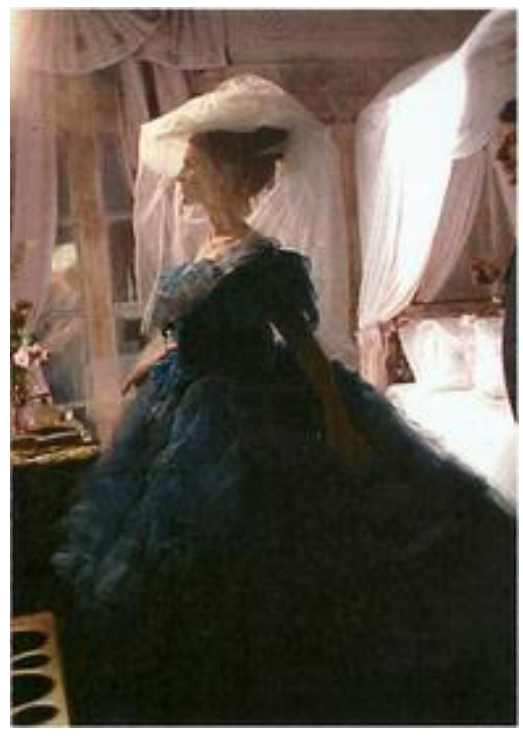

Figura 12

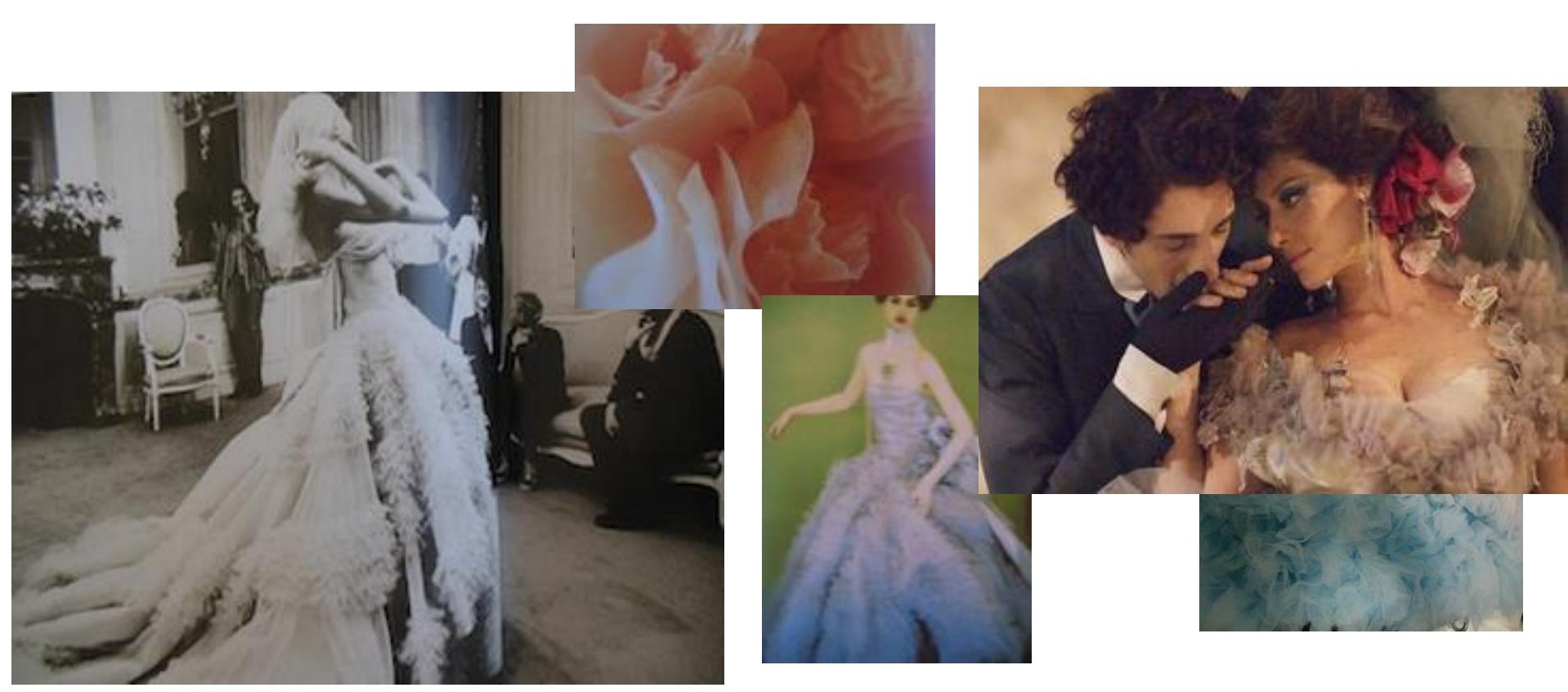

Figura 13 


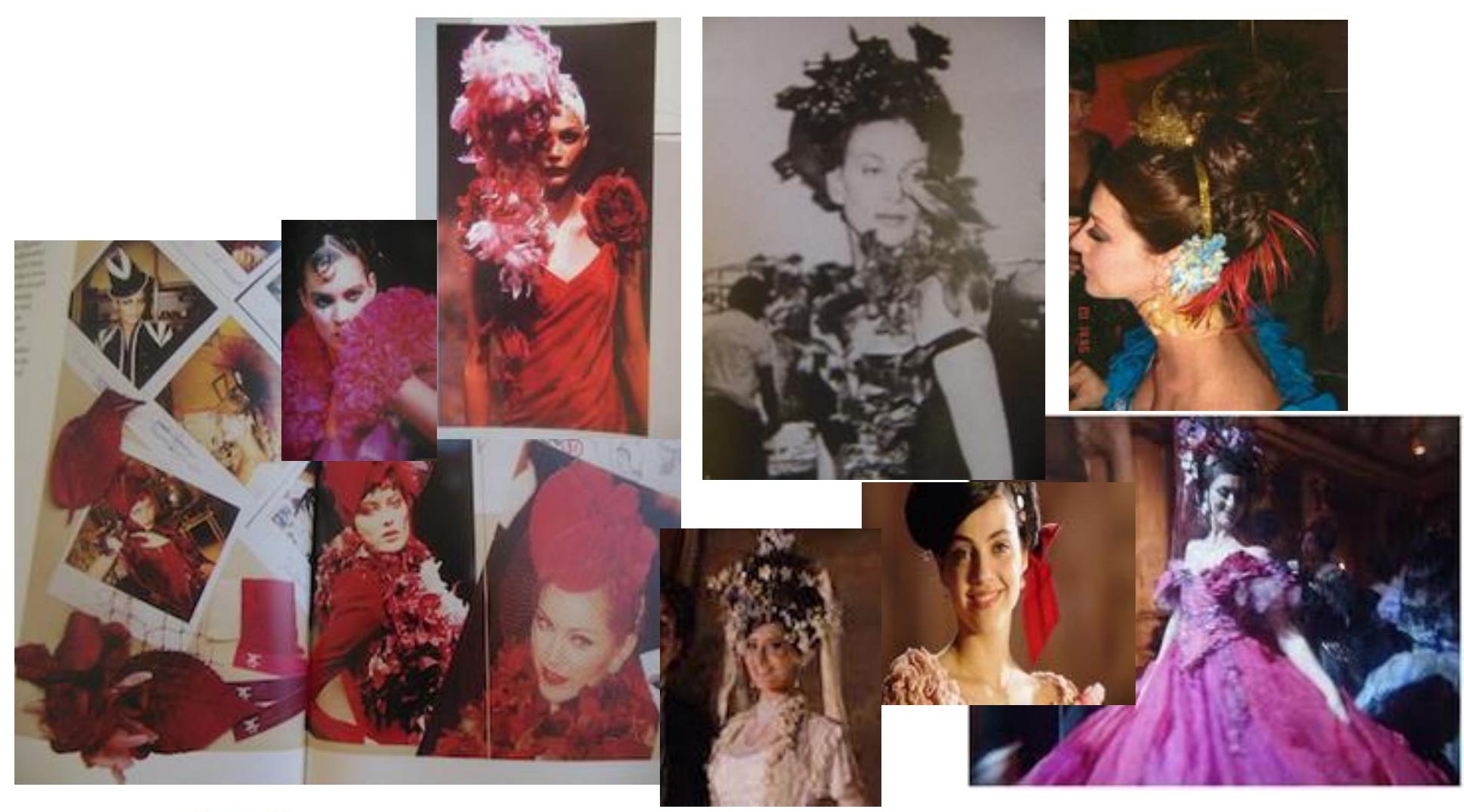

Figura 14 


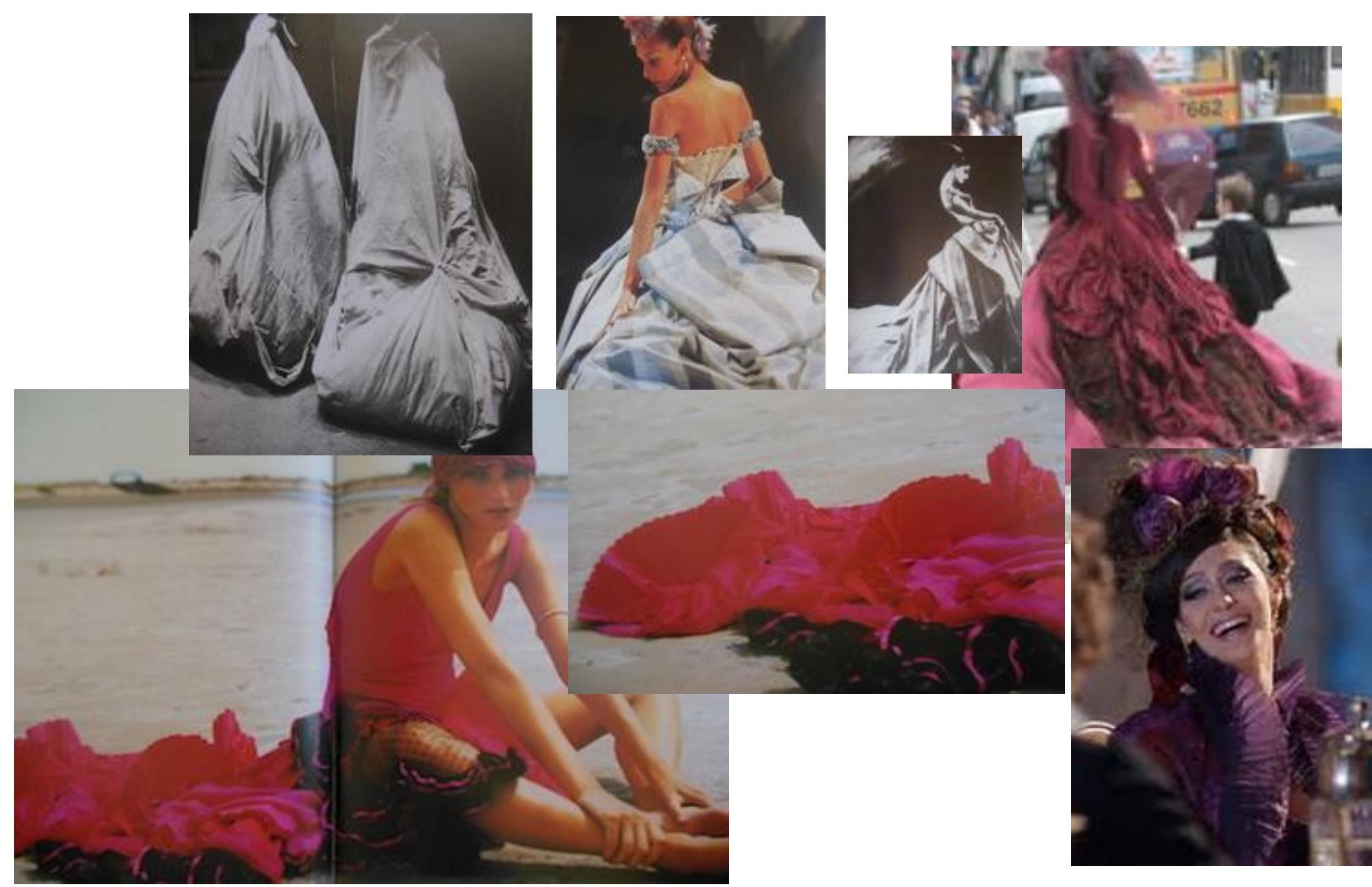

Figura 15

As pregas são profundas e possuem grandes repuxados. A saia alcança seu maior volume e circunferência com o auxílio de uma grande crinolina. Segundo Menezes, referindo-se à estrutura que a crinolina empresta à roupa: "Os figurinos estão livres dos excessos de domestificação. São roupas turbulentas, belas, vivas, nas gaiolas dos seus quatro metros de armação e saia". ${ }^{22} \mathrm{O}$ próprio movimento da saia reproduz o vai e vem do mar, sedutor e cadenciado. Como descreve o teórico da moda James Laver:

A crinolina estava em constante estado de agitação, balançando de um lado para o outro. Era como um balão cativo bastante agitado, em nada, exceto na forma, como os iglus dos esquimós. Balançando ora para um lado, ora para o outro, inclinando-se um pouco, balançando para frente e para trás. Qualquer pressão sobre um dos lados dos aros de aço refletia

22 MENEZES, “Arte na TV”, Luz e Cena, p. 44. 
por sua elasticidade no outro lado, e resultava em súbito disparo da saia para cima. ${ }^{23}$

As roupas continuam sendo montadas de acordo com a necessidade das cenas e do corpo da atriz, a qual se encontrava grávida e já com barriga avançada, o que alterava suas medidas constantemente (figura 16):

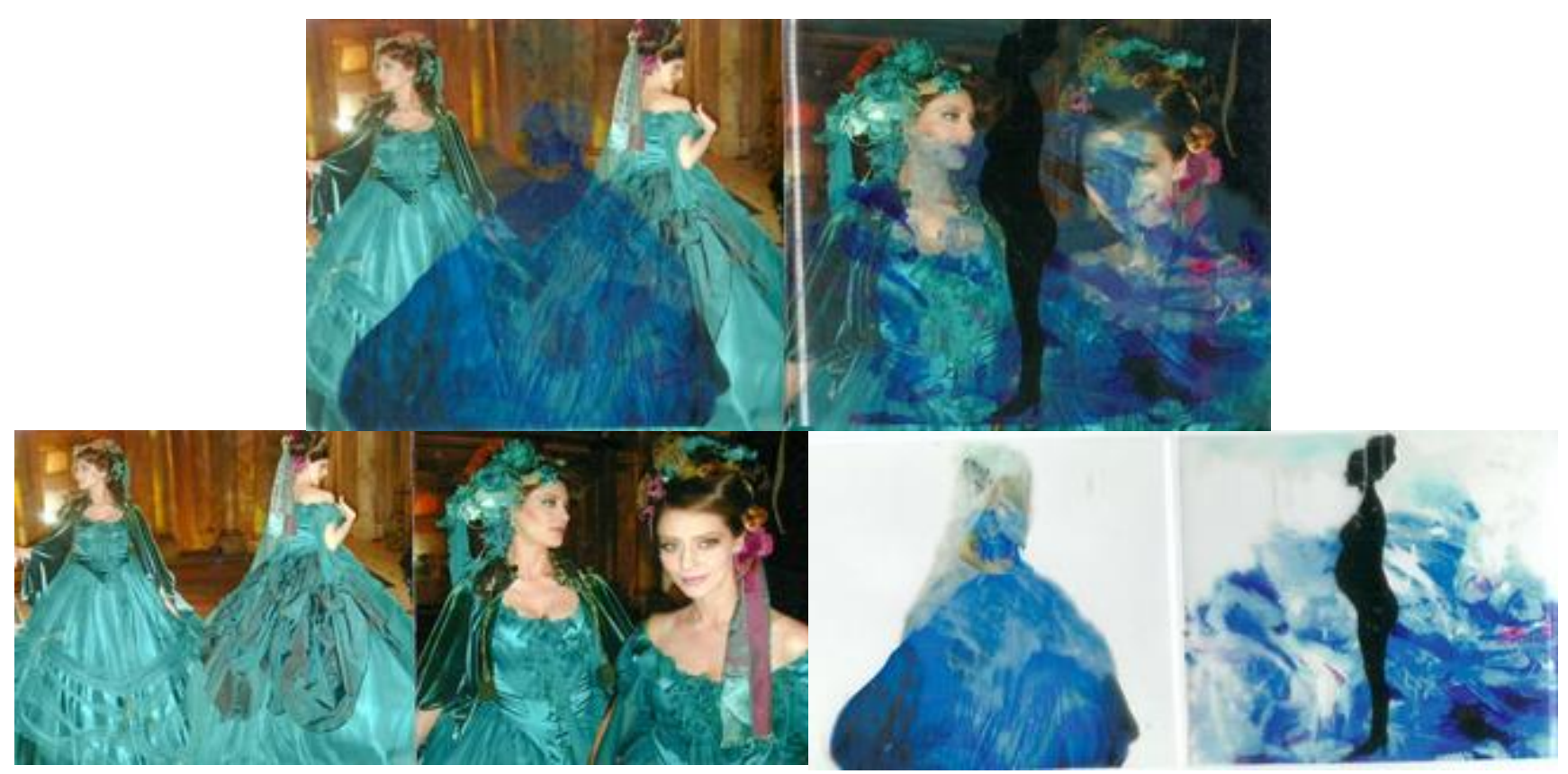

Figura 16

Os corpetes de Capitu feitos para Maria Fernanda Cândido eram abertos atrás e amarrados para conforto de seu corpo. Capitu, que já tinha a base "larga" e ampla, aumenta ainda mais. Além disso, a silhueta de saia exagerada ajuda a equilibrar a figura da atriz escondendo-lhe a gravidez. $\mathrm{O}$ equilíbrio se mostrou exato, funcionava para a cena e para a obra. A silhueta crescente não destoava; pelo contrário, foi de tal forma incorporada pela filosofia construtiva imagética que, na época, a gravidez da atriz passou despercebida. Em cena, não se notava que a atriz estava grávida, embora já

23 "The crinoline was in a constant state of agitation, swaying from side to side. It was like a rather restless captive balloon, and not at all, except in shape, like the igloo of the Eskimos. It swayed now to one side, now to the other, tipped up a little, swung forward and backward. Any pressure on one side of the steel hoops was communicated by their elasticity to the other side, and resulted in a sudden upward shooting of the skirt." LAVER apud BRUZZI, Undressing Cinema: Clothing and Identity in the Movies, p. 38 . 
beirasse o terceiro trimestre. $\mathrm{O}$ restante da roupa era montado, como antes: de acordo com as necessidades, acumulavam-se no corpo golas, rendas, detalhes, que se ressignificavam a cada momento. Seguem, por último, fotos tiradas de detalhes dos figurinos, das pequenas camadas, dos caquinhos e florzinhas, bordados, exemplo de todo o trabalho manual que esse figurino carrega e que enriquece tanto sua imagem (figura 17):

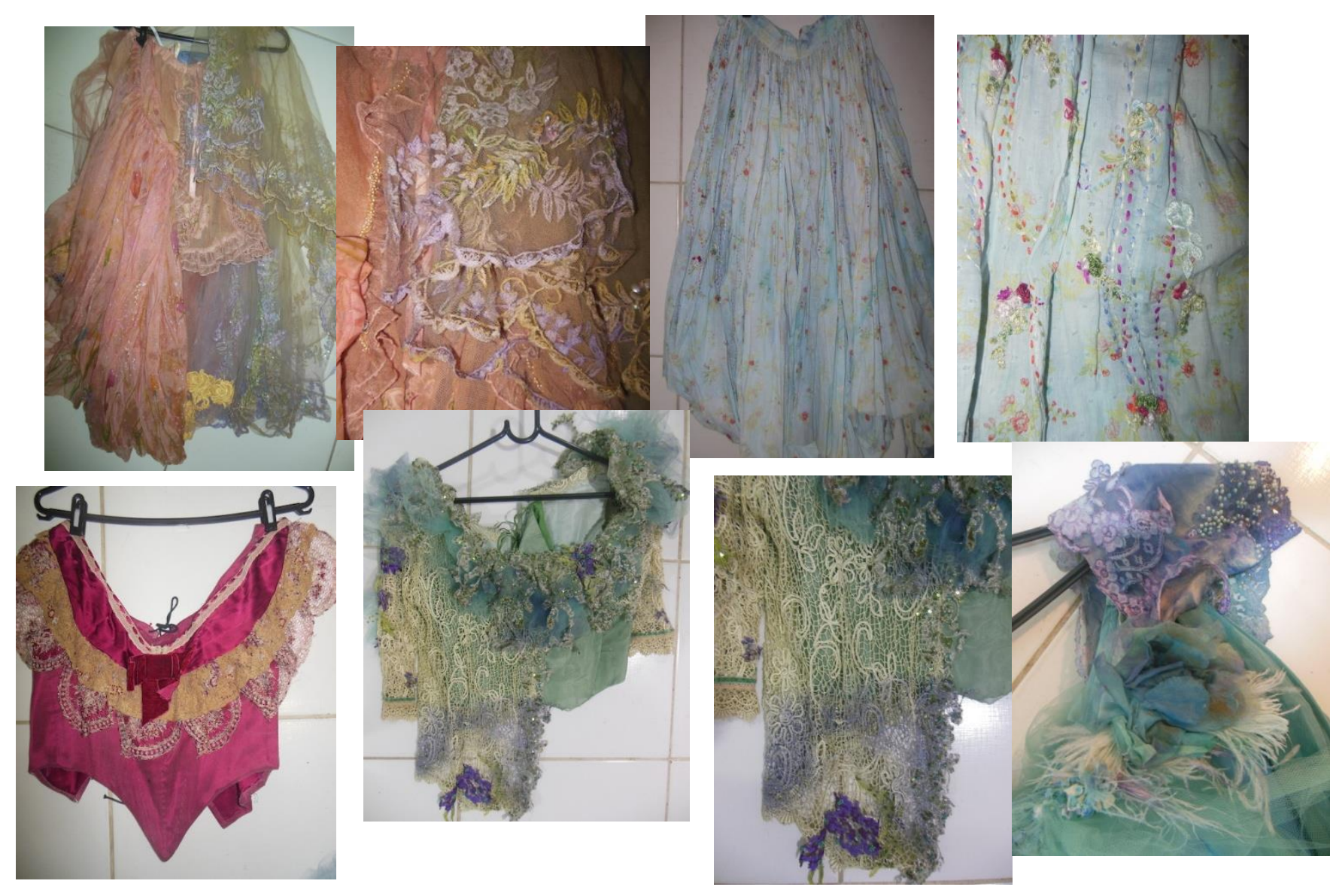

Figura 17

O figurino de Capitu brota das entranhas de Dom Casmurro, se aquece na luz de seu olhar e verte nesse solo, como água, como Capitu oceano das memórias do narrador. Ela é o que dele brota. E ela ora jorra, ora inunda, encharcando todo o ambiente, envolvendo todos os habitantes daquele mundo. Capitu de orvalho/espuma leve, o mar em toda sua plenitude. Ela é, em sua relação com Dom Casmurro e seus desdobramentos, o movimento oscilatório das ondas. E como tudo e todos são gerados nesse ambiente, tudo e todos são influenciados por suas águas e pelo olhar que a olha, todos os 
cenários daquele casarão antigo são matéria das organicidades de Dom Casmurro:

Uma posição adquirida pela antropologia é a de que não há nada de natural no corpo. O corpo não é natural porque, em cada cultura e em cada indivíduo, o corpo é constantemente preenchido por sinais e símbolos. Não somente não há nada de natural no corpo, mas também a pele não é o seu limite: e quando a pele transpõe seus limites, ela se liga aos tecidos "orgânicos" da metrópole. Nesse sentido, o corpo não é apenas corporal. O corpo expandido em edifícios, coisas-objetosmercadorias, imagens, é aquilo que se entende aqui por fetichismo visual. $^{24}$

São corpos ligados à arquitetura interior de Dom Casmurro, pele que transcende o tecido, que se metamorfoseia em cenário, tornando-se figurinoinstalação.

Capitu transforma-se no epicentro da criação: "Capitu gira, impregnando tudo e todos", diz Filipecki; a dobra e as águas ditaram forma e ritmo, e Capitu impregnou formalmente e respingou suas tintas por aí. Nas palavras de Deleuze:

[...] as dobras da vestimenta ganham autonomia, amplitude, e não apenas por um simples cuidado de decoração mas para exprimir a intensidade de uma força espiritual que se exerce sobre o corpo, seja para revertê-lo, seja para reestabelecê-lo ou para elevá-lo, mas sempre para revolvê-lo e moldar seu interior. ${ }^{25}$

Filipecki é levada pelas mãos de Machado de Assis, como se o texto e suas características de conteúdo e forma moldassem o processo de construção do figurino. $\mathrm{E}$ nesse momento, a personagem ganha vida e apresenta suas exigências e necessidades que ampliam ou focam os caminhos e atalhos dos "gatilhos" de trabalho da figurinista. Esse movimento faz o trabalho transcender ao tempo, às formas datadas. Como um tecido único em movimento conecta palavras, imagens, formas e conceitos.

Quanto a sua imagem, a personagem Capitu aparece então para o público carregada de seus conceitos e espaços, construída para comunicar o fato de ser uma interseção entre o que existiu, o que Bentinho/Bento gerou e

${ }^{24}$ CANEVACCI, cit., p. 18.

${ }^{25}$ DELEUZE, cit., p. 209. 
o que restou no narrador, impregnando suas lembranças e todos os que nela residem. Talvez suas formas se aproximem mais dela mesma (como a pessoa original com a qual ele conviveu, segura dos jogos e ciente das suas dobras de personalidade) e do afeto físico da presença de seu corpo no corpo de Dom Casmurro; e suas cores (que merecem uma análise à parte) se apresentem num rebatimento do olhar do personagem narrador e com muito efeito no funcionamento de sua memória.

Quanto maior e mais profunda a pesquisa, mais gatilhos criativos se conquistam e se desenvolvem para a construção seja de um texto, de uma análise, de um objeto material, como o figurino. Assim como o atravessamento dessas questões nas diversas áreas artísticas, contaminadas pela teoria literária, plástica e pela crítica. O conhecimento teórico respinga onde ele for interessante para o corpo do trabalho que se deseja realizar, seja ele plástico ou onírico.

\section{Referências}

ARISTÓTELES. Da alma. São Paulo: Editora Edipro, 2011.

ASSIS, Machado de. Dom Casmurro. Rio de Janeiro: Nova Fronteira, 2011.

BACHELARD, Gastón. A poética do espaço. São Paulo: Martins Fontes, 2012.

BAUDRILLARD, Jean. "O trompe-l'oeil". In: A arte da desaparição. Rio de Janeiro: Editora UFRJ, 1997.

BOSI, Alfredo. Machado de Assis: o enigma do olhar. São Paulo: Martins Fontes, 2007.

BRUZZI, Stela. Undressing Cinema: Clothing and Identity in the Movies. London: Taylor \& Francis, 1997.

CANEVACCI, Mássimo. Fetichismos visuais: corpos erópticos e metrópole comunicacional. São Paulo: Ateliê Editorial, 2008.

DELEUZE, Gilles. A dobra: Leibniz e o barroco. São Paulo: Papirus, 2012.

DIDI-HUBERMAN, Georges. "A imagem crítica". In: O que vemos, o que nos olha. São Paulo: Editora 34, 1998.

FILIPECKI, Elizabeth. Entrevista a Luz e Cena, Rio de Janeiro, n. 113, p.36-45, dez. 2008.

GASKELL, George. "Entrevistas individuais e grupais". In: Pesquisa qualitativa com texto, imagem e som: um manual prático. Petrópolis: Vozes, 2002.

GIL, José. "O desaparecer da natureza". In: Sem título: escritos sobre outros artistas. Lisboa: Relógio d'Água, 2005.

GIL, José; LINS, Daniel (Orgs.). Nietzsche Deleuze: jogo e música. São Paulo: Editora Forense, 2008. 
ISER, Wolfgang. O fictício e o imaginário. Rio de Janeiro: EdUERJ, 2002.

JOVCHELOVICH, Sandra; BAUER, Martin W. "Entrevista narrativa". In: Pesquisa qualitativa com texto, imagem e som: um manual prático. Petrópolis: Vozes, 2002.

MANGUEL, Alberto. Lendo imagens. São Paulo: Companhia das Letras, 2001.

McDOWELL, Colin. Galliano. London: Weidenfeld \& Nicolson, 1997.

MENEZES, Elisa. "Arte na TV”. Luz e Cena, Rio de Janeiro, n. 113, p.36-45, dez. 2008

NICOLACI-DA-COSTA, Ana Maria. "O campo da pesquisa qualitativa e o Método de Explicitação do Discurso Subjacente (MEDS)". Psicologia: Reflexão e Crítica, Porto Alegre, v. 20, n. 1, p. 65-73, 2007. Disponível em: http://www.scielo.br/scielo.php?script=sci_arttext\&pid=S0102-

79722007000100009\&lng=en\&nrm=iso. Acesso em: 24 maio 2013.

PELLEGRINI, Tânia (Org.). Literatura, cinema e televisão. São Paulo: Editora Senac, 2003.

RIBAS, Martha (coord. ed.). Capitu. Rio de Janeiro: Casa da Palavra, 2008.

RIBEIRO, Marianna Millecco. Capitu: análise de um figurino e por um resgate e reconstrução da metodologia de trabalho de Beth Filipecki. Dissertação (Mestrado em Artes Visuais). Rio de Janeiro, Universidade Federal do Rio de Janeiro, 2015.

ROSE, Diana. "A análise de imagens em movimento". In: Pesquisa qualitativa com texto, imagem e som: um manual prático. Petrópolis: Vozes, 2002.

SEIVEWRIGHT, Simon. Pesquisa e design: fundamentos de design de moda. São Paulo: Bookman, 2009.

WITTGENSTEIN, Ludwig. "O ser humano na campânula vermelha (fragmento de carta)". In: Luz e sombras: uma experiência (onírica) noturna e um fragmento de carta. São Paulo: Martins Fontes, 2012.

MARIANA MILLECCO é figurinista e pesquisadora graduada e pós-graduada na Universidade Federal do Rio de Janeiro, na linha de História e Crítica da Arte - Imagem e Cultura. Autora de "As cores como indício da construção poética: estudo de caso da personagem Capitu", artigo apresentado e publicado no CIMODE em Milão. E-mail: m.millecco@gmail.com. 